\title{
Independent evolutionary lineage of the clingfish Gobiesox adustus (Gobiesocidae) from Isla del Coco, Costa Rica
}

\author{
Eloísa Torres-Hernández ${ }^{1}$, Isai Betancourt-Resendes², Píndaro Díaz-Jaimes ${ }^{3}$, Arturo Angulo ${ }^{4}$, \\ Eduardo Espinoza ${ }^{5}$ \& Omar Domínguez-Domínguez ${ }^{6 *}$
}

1. Posgrado en Ciencias del Mar y Limnología, Universidad Nacional Autónoma de México; Av. Ciudad Universitaria 3000, C.P. 04510, Coyoacán, Ciudad de México, México; eltorres18@gmail.com

2. CONACYT-Laboratorio de Zoología, Facultad de Ciencias Naturales. Universidad Autónoma de Querétaro. Av. De las Ciencias s/n, Juriquilla, C.P 76230. Delegación Santa Rosa Jáuregui, Santiago de Querétaro, México; bq_isai7@yahoo.com.mx

3. Instituto de Ciencias del Mar y Limnología, Universidad Nacional Autónoma de México; Av. Ciudad Universitaria 3000, C.P. 04510, Coyoacán, Ciudad de México, México; pindaro@cmarl.unam.mx

4. Museo de Zoología y Centro de Investigación en Ciencias del Mar y Limnología, (CIMAR), Universidad de Costa Rica, San Pedro de Montes de Oca, 11501-2060, San José, Costa Rica; arturo.angsib@gmail.com

5. Dirección del Parque Nacional Galápagos, Puerto Ayora, Islas Galápagos, Ecuador; eespinoza@galapagos.gob.ec

6. Laboratorio de Biología Acuática, Facultad de Biología. Universidad Michoacana de San Nicolás de Hidalgo. Ciudad Universitaria s/n, C.P. 58030, Morelia, Michoacán, México; goodeido@yahoo.com.mx

* Correspondence

Received 05-II-2019. C Corrected 25-IV-2019. Accepted 18-VI-2019.

\begin{abstract}
Introduction: Isla del Coco is an important protected area for marine fauna in the Eastern Tropical Pacific. In this area, the species that inhabit the intertidal zone have been subject to few studies. One of the species inhabiting these areas is the clingfish Gobiesox adustus (Gobiesocidae). Objective: To analyze for the first time the mitochondrial gene cytochrome oxidase subunit 1 ( $\operatorname{cox} 1)$ of $G$. adustus' population from Isla del Coco and compare it with those of continental coast of Costa Rica and Ecuador. Methods: We constructed a haplotype network for these samples. Genetic diversity, distance and structure were calculated by several software. The historical demography of Isla del Coco samples was assessed with the method Bayesian skyline plot as implemented in BEAST2. Results: The samples segregate into three haplogroups: one consisting of the Isla del Coco samples, a second consisting of a subset of the Ecuador samples, and a third consisting of Costa Rica and the remaining Ecuador samples. The genetic distances between the three haplogroups range between $1.6 \%$ and $2.1 \%$ (uncorrected $p$-distance), and pairwise ФST and AMOVA results between the three haplogroups show high and significant values. Conclusions: The Isla del Coco haplogroup showed a Pleistocene population growth, which agrees with demographic patterns found in other marine organisms. The history of isolation of the G. adustus population from Isla del Coco demonstrates the evolutionary independence of this population.
\end{abstract}

Key words: Clingfish; Cryptobenthic; Ocean Island; Marine Fish; Intertidal; Eastern Tropical Pacific.

Torres-Hernández, E., Betancourt-Resendes, I., Díaz-Jaimes, P., Angulo, A., Espinoza, E., \& Domínguez-Domínguez, O. (2020). Independent evolutionary lineage of the clingfish Gobiesox adustus (Gobiesocidae) from Isla del Coco, Costa Rica. Revista de Biología Tropical, 68(Suppl. 1), S306-S319.

Oceanic islands are recognized for their great value in developing human understanding of evolutionary processes in marine environments, acting as small "living laboratories" where species adapt and diversify. Where suitable protection measures exist, such islands are also important refuges against biodiversity loss from overexploitation (Robertson, 2001; Losos \& Ricklefs, 2009). Island diversity is controlled by the equilibrium between migration and extinction, as well as by speciation rates. These processes are linked to the size of the island 
and the proximity of the island to the biodiversity source (such as the continent) (Whittaker, Triantis, \& Ladle, 2008). Others factors that can influence the species richness of islands are the heterogeneity of the terrain, oceanographic processes, and geological history (Robertson, 2001; Hachich et al., 2015). Gene flow restriction is an important mechanism for the formation and maintenance of reef fish endemism on islands, where the degree of isolation of the island from the main source of diversity input, as well as the age of the island, are key factors in the number of endemic species (Hachich et al., 2015). It is expected that older islands will have more endemic species compared to younger islands, as a result of a longer time over which speciation processes may have acted on them (Emerson \& Kolm, 2005).

Isla del Coco is located 600 kilometers South of Puntarenas, Costa Rica and $630 \mathrm{~km}$ to the Northeast of the Galapagos Islands of Ecuador; is part of the biogeographic region of the Eastern Tropical Pacific (ETP) (Garrison, 2000; Robertson \& Cramer, 2009). Isla del Coco is the largest national park in Costa Rica (Cortés, 2008). Research on the island's ichthyofauna has focused mainly on reef shark species and species of commercial interest (Cortés, 2012; Cortés et al., 2012; Gonzáles-Andrés, Lopes, Cortés, J., Sánchez-Lizaso, \& Pennino, 2016; Fourriére, Alvarado, Ayala-Bocos, \& Cortés, 2017). Cryptobenthic fishes are a component of marine ichthyofauna that has been poorly studied due to the difficulties associated with observation, sampling, and identification (Willis, 2001; Ackerman \& Bellwood, 2002; Depczynski \& Bellwood, 2003). The use of different substance like rotenone, quinaldine or clove oil to sampling cryptobenthic fish reveals species usually undetected with visual methods or other collection techniques; and the richness and diversity is underestimate (Ackerman \& Bellwood, 2000; Robertson \& Smith-Vaniz, 2008). Cryptobenthic fish have an important role in the reef ecosystem, cycling trophic energy from microscopic or detrital prey items to larger consumers and they can be important indicators to changes in environmental conditions (Bellwood et al., 2012; Brandl, Goatley, Bellwood, \& Tornabene, 2018).

The family Gobiesocidae (clingfishes), are small cryptobenthic fishes adapted to live in intertidal zones or rocky coasts. Clingfish are found in marine and freshwater habitats, in temperate and tropical areas (Thomson, Findley, \& Kerstitch, 2000). Clingfish are best representative in the ETP with 31 endemic species that Greater Caribbean with 27 species (Robertson \& Allen, 2015).

Gobiesox adustus Jordan \& Gilbert, 1882 is distributed from the Gulf of California to Ecuador, including the islands Revillagigedo and Marias (México), and Isla del Coco (Costa Rica) (Robertson \& Allen, 2015). We evaluated for the first time, variation in the mitochondrial marker cytochrome oxidase sub-unit 1 (coxl) for the Gobiesox adustus population of Isla del Coco and continental populations from Costa Rica and Ecuador. The cox 1 gene is widely used for the identification of the species through the International Barcode of Life project (iBOL) (Hebert, Cywinska, Ball, \& deWaard, 2003; Hebert, Ratnasingham, S., \& deWaard, 2003; Hollingsworth, Graham, \& Little, 2011; Al-Rshaidat et al., 2016; Andújar, Arribas, Yu, Vogler, \& Emerson, 2018). The sequencing of the coxl gene has played an important role in the identification of cryptic species and the increase in the rate of new species discovery (Hebert et al., 2003a; Ward, Zemlak, Innes, Last, \& Hebert, 2005; Sáenz, 2009; Valdéz-Moreno, Vásquez-Yeomans, Elías-Guitiérrez, Ivanova, \& Hebert, 2010). More recently, this marker has been used in a phylogeographic framework to investigate the genetic connectivity or fragmentation along the distribution range of a species (Briggs \& Bowen, 2012), to investigate the evolutionary history of species and the current dynamics of the populations. The objectives of the present work were: i) to elucidate if the isolation effect could be affecting the genetic structure of $G$. adustus and ii) to determine the evolutionary histories of G. adustus from Isla del Coco and southern continental populations and their conservation implications. 


\section{MATERIALS AND METHODS}

Specimen collection and sampling: Sampling was carried out in rocky intertidal pools on Isla del Coco and in continental sampling locations from Costa Rica and Ecuador (Fig. 1; Table 1). Clove oil and hand nets were used following the protocol of Torres-Hernández et al. (2016). Tissue samples (fin clips) were obtained from each organism, preserved in absolute ethanol, and stored at $-75^{\circ} \mathrm{C}$. Voucher specimens were deposited in the ichthyological collection of the 'Universidad Michoacana de San Nicolás de Hidalgo', Mexico (CPUM, SEMARNAT registration number MICH.PEC227-07-09) (Table 1).

DNA extraction, amplification, and sequencing: DNA extraction was carried out using the proteinase $\mathrm{K}$ and phenol-chloroform protocol (Sambrook, Fritsch, \& Maniatis, 1989). The mitochondrial cytochrome oxidase sub-unit 1 gene (coxl: 621 base pair) was amplified with the primers Fish1F/Fish1R (Ward et al., 2005) and LCO1490F/HCO2198R (Folmer, Black, Hoeh, Lutz, \& Vrijenhoek, 1994), by means of polymerase chain reactions (PCRs), in $12.5 \mu \mathrm{l}$ volume reaction containing: $1.25 \mu \mathrm{l}$ of the buffer (buffer Tris-HCL 10X with $\left.\mathrm{MgCl}_{2}\right), 0.3125 \mu \mathrm{l} \mathrm{MgCl}_{2}(50 \mathrm{mM}), 0.5$ $\mu \mathrm{l}$ of each primer $(10 \mathrm{mM}), 0.5 \mu \mathrm{l}$ of dNTPs $(10 \mathrm{mM}), 0.125 \mathrm{U} / \mu \mathrm{l}$ of Taq DNA polymerase (Invitrogen) and $1 \mu \mathrm{l}(10-60 \mathrm{ng})$ of DNA template. The thermocycling conditions for Fish1F/Fish1R consisted of an initial denaturation step at $94^{\circ} \mathrm{C}(5 \mathrm{~min})$ followed by 36 cycles at $94^{\circ} \mathrm{C}(1 \mathrm{~min})$ for DNA denaturation, $52^{\circ} \mathrm{C}(1 \mathrm{~min})$ for annealing, and $72^{\circ} \mathrm{C}(1 \mathrm{~min})$ for synthesis, with a final extension at $72^{\circ} \mathrm{C}$ (10 min). For LCO/HCO we followed Conway et al., (2017). The PCR products were purified with Exo-SAP-IT (USB Corp. Cleveland, OH, USA) and submitted to Macrogen Inc. (Korea) for sequencing. Sequences were manually aligned and examined using chromatograms in MEGA v7 (Kumar, Stecher, \& Tamura, 2016).

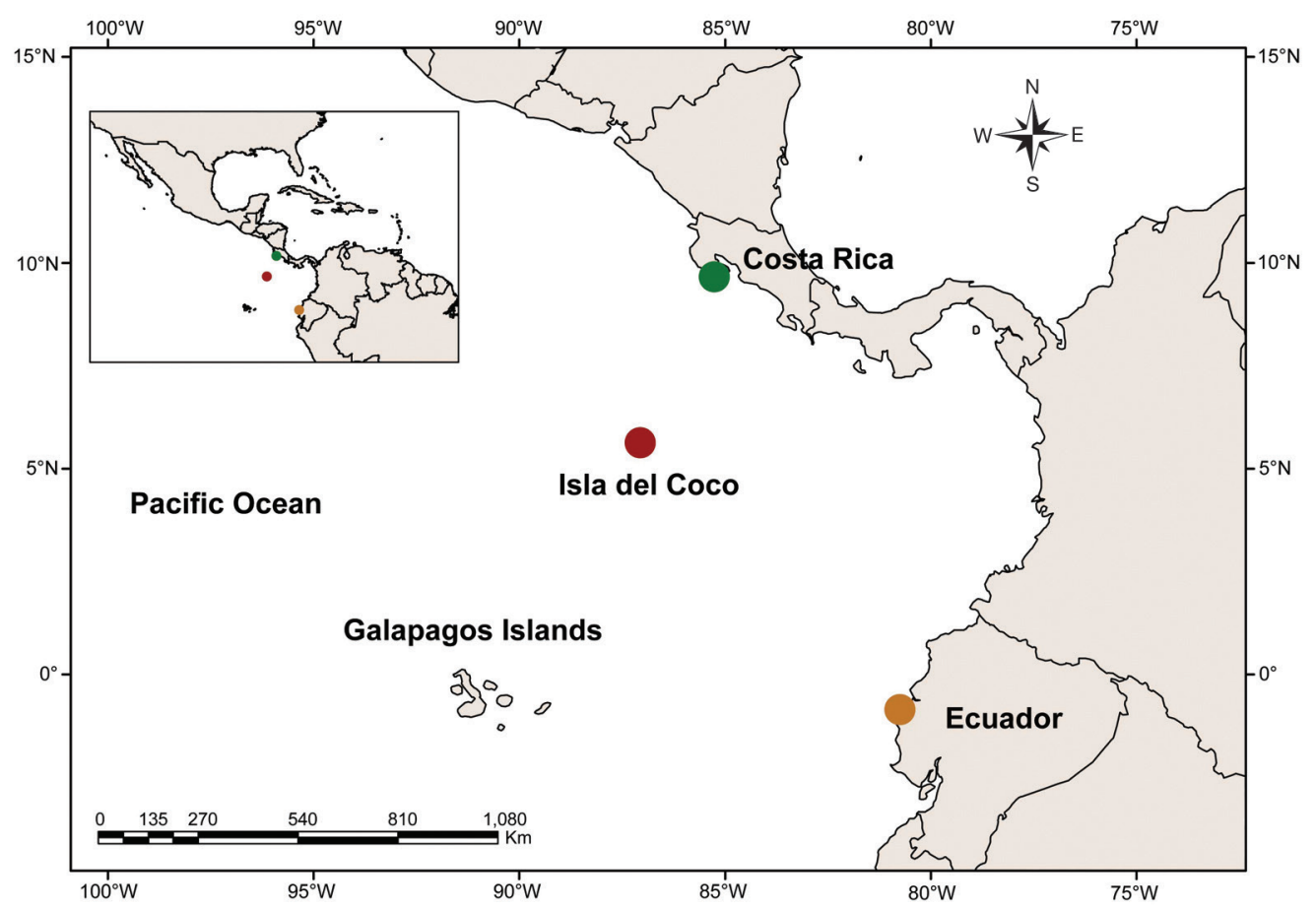

Fig. 1. Geographic location of samples of Gobiesox adustus included in this study. 
TABLE 1

Accession numbers for GenBank of each sequence for coxl. Collection information: tissue ID, CPUM ID, sampling location, coordinates and country

\begin{tabular}{|c|c|c|c|c|c|c|}
\hline Specie & Tissue ID & $\begin{array}{c}\text { Collection } \\
\text { ID (CPUM) }\end{array}$ & $\begin{array}{c}\text { GenBank } \\
\text { access } \operatorname{cox} 1\end{array}$ & Sampling location & Coordinates & Country \\
\hline \multirow[t]{23}{*}{$\begin{array}{l}\text { Gobiesox } \\
\text { adustus }\end{array}$} & 21551 & $\mathrm{n} / \mathrm{d}$ & MN539444 & $\begin{array}{l}\text { Pool in Reserva } \\
\text { San Miguel, Cabo Blanco, } \\
\text { Puntarenas }\end{array}$ & $\begin{array}{l}9^{\circ} 34^{\prime} 47.6^{\prime \prime} \mathrm{N}, \\
85^{\circ} 8 \text { '12.9”W }\end{array}$ & Costa Rica \\
\hline & 47056 & 12760 & MN539445 & \multirow{12}{*}{$\begin{array}{l}\text { Tidepool } \\
\text { Bahía Wafer, } \\
\text { Isla del Coco }\end{array}$} & \multirow{12}{*}{$\begin{array}{l}5^{\circ} 32^{\prime} 46.15^{\prime \prime} \mathrm{N}, \\
87^{\circ} 3{ }^{\prime} 26.69^{\prime} \mathrm{W}\end{array}$} & \multirow[t]{12}{*}{ Costa Rica } \\
\hline & 47128 & $\mathrm{n} / \mathrm{d}$ & MN539446 & & & \\
\hline & $\begin{array}{c}47643- \\
47660\end{array}$ & $\mathrm{n} / \mathrm{d}$ & $\begin{array}{l}\text { MN539447- } \\
\text { MN539464 }\end{array}$ & & & \\
\hline & 47671 & $\mathrm{n} / \mathrm{d}$ & MN539465 & & & \\
\hline & 47672 & $\mathrm{n} / \mathrm{d}$ & MN539466 & & & \\
\hline & 47673 & $\mathrm{n} / \mathrm{d}$ & MN539467 & & & \\
\hline & 47677 & $\mathrm{n} / \mathrm{d}$ & MN539468 & & & \\
\hline & 47678 & $\mathrm{n} / \mathrm{d}$ & MN539469 & & & \\
\hline & 47679 & $\mathrm{n} / \mathrm{d}$ & MN539470 & & & \\
\hline & 48368 & $\mathrm{n} / \mathrm{d}$ & MN539471 & & & \\
\hline & $\begin{array}{c}48489- \\
48511\end{array}$ & $\mathrm{n} / \mathrm{d}$ & $\begin{array}{l}\text { MN539472- } \\
\text { MN539494 }\end{array}$ & & & \\
\hline & $\begin{array}{c}48556- \\
48563\end{array}$ & $\mathrm{n} / \mathrm{d}$ & $\begin{array}{l}\text { MN539495- } \\
\text { MN539502 }\end{array}$ & & & \\
\hline & 51501 & 12638 & MN539503 & \multirow{10}{*}{$\begin{array}{l}\text { Ligüiqui } \\
\text { (Tidepool), } \\
\text { Manabi }\end{array}$} & \multirow{10}{*}{$\begin{array}{l}0^{\circ} 55^{\prime} 38.2^{\prime \prime} \mathrm{N}, \\
80^{\circ} 44^{\prime} 25.4^{\prime} \mathrm{W}\end{array}$} & \multirow[t]{10}{*}{ Ecuador } \\
\hline & 51503 & & MN539504 & & & \\
\hline & 51525 & $\mathrm{n} / \mathrm{d}$ & MN539505 & & & \\
\hline & 51526 & $\mathrm{n} / \mathrm{d}$ & MN539506 & & & \\
\hline & 51532 & 12638 & MN539507 & & & \\
\hline & 57338 & $\mathrm{n} / \mathrm{d}$ & MN539508 & & & \\
\hline & 57339 & $\mathrm{n} / \mathrm{d}$ & MN539509 & & & \\
\hline & 57340 & $\mathrm{n} / \mathrm{d}$ & MN539510 & & & \\
\hline & 57363 & $\mathrm{n} / \mathrm{d}$ & MN539511 & & & \\
\hline & 57369 & $\mathrm{n} / \mathrm{d}$ & MN539512 & & & \\
\hline
\end{tabular}

The sequences obtained were deposited in the GenBank database (http://www.ncbi.nlm.nih. gov/gengank/) under accession numbers shown in Table 1. The best-fit model for the data set was calculated in jModeltest v (Posada, 2008) based on the corrected Aikake Information Criterion (AIC).

\section{Haplotype network and genetic diver-} sity: Intraspecific relationships among the samples were inferred through a haplotype network constructed in PopArt v.1.7 (http:// popart.otago.ac.nz) applying the Median-Joining method (Bandelt, Forster, \& Röhl, 2000).
Genetic diversity was assessed by means of the following measures: 1) haplotype diversity $(h), 2)$ nucleotide diversity $(\pi)$, and 3 ) segregating sites (S) using DnaSP v5.10 (Librado \& Rozas, 2009).

Genetic distance and structure: Levels of genetic differentiation and structure among haplogroups of Gobiesox adustus were estimated using uncorrected pairwise genetic distances ( $p$-distance) calculated in MEGA v.7 with 1000 bootstrap replicates and using the statistic $\Phi S T$ (as an alternative fixation index used for haplotype data) by means of pairwise comparisons 
and analysis of molecular variance (Weir \& Cockerham, 1984; Excoffier, Smouse \& Quattro, 1992; AMOVA; Dupanloup, Schneider, \& Excoffier, 2002) with a significance level of $\alpha=0.05$ and 1,000 random permutations implemented in the software Arlequin v.3.5.1.2 (Excoffier \& Lischer, 2010).

Historical demography: The historical demography of Isla del Coco samples was assessed with the method Bayesian skyline plot (Drummond, Rambaut, Shapiro, \& Phybus, 2005)This coalecsent-based methods provide a robust framework to infer past population dynamics through time from a DNA sequences without dependence on a prespecified parametric model of demographic history implemented in BEAST2 (Bouckaert et al., 2014). The analysis was carried out using an uncorrelated lognormal relaxed clock model. Since no mutation rate for cox 1 in Gobiesocidae is available, we use the mutation rate available for Gobiidae, a close related group that is part of the Gobiesociformes, of 1.81 to $2.04 \%$ widely used for reef fish species (Keith et al., 2011), using a uniform prior (lower $=0.009$ and upper $=0.01$ substitutions $/$ site/million year). The webserver CIPRES Science Gateway v. 3.3 (Miller, Pfeiffer, \& Schwartz, 2010) was implemented, using the Markov Chain Monte Carlo algorithm (MCMC) run for 50 million generations sampled every 1000 generations. The Bayesian reconstruction graph was carried out in Tracer software v1.4 (Rambaut \& Drummond, 2007).

\section{RESULTS}

We obtained a partial fragment of the cox1 mitochondrial gene for 69 individuals of Gobiesox adustus from Costa Rica ( $\mathrm{n}=1)$, Ecuador $(n=10)$ and Isla del Coco $(n=58)$. The length of the alignment was 621 base pairs, of which 566 were invariable, 34 variable, and 27 parsimony informative. The best-fit substitution model for the aligned data was $\operatorname{TrN}+\mathrm{I}$.
Haplotype network: The haplotype network resulted in 31 haplotypes divided into three haplogroups (Fig. 2). The individuals of Isla del Coco appear segregated into one haplogroup (haplogroup 3) and did not share haplotypes with samples from the continental coast (Ecuador and Costa Rica). Haplogroup 3 is separated by 11 mutational steps from haplogroup 1 , which is formed by samples from Ecuador. Haplogroup 2 is formed by the samples collected in the mainland of Costa Rican and two samples from Ecuador, and is separated by seven mutational steps from the Isla del Coco (haplogroup 3) and 11 mutational steps from haplogroup 2 (Fig. 2). The genetic diversity by haplogroup is shown in Table 2. The genetic diversity was high and the nucleotide diversity was low for the three haplogroups.

Genetic differentiation and structure: Pairwise $\Phi S T$ values among the three haplogroups of Gobiesox adustus showed high and significant values (Table 3 ). The highest value was between haplogroup 1 (Ecuador) and haplogroup 2 (Costa Rica-Ecuador) ( $\Phi S T=0.941)$. The uncorrected mean genetic distances ( $p$-distances) calculated between haplogroups were also high (Table 3). The $p$-distance for haplogroup 3 (Isla del Coco) vs haplogroup 1 and 2 was calculated as $2.1 \%$, for haplogroup 3 vs 2 was $1.6 \%$. The AMOVA show significant values for the three haplogroups $(\Phi S T=0.688$ $P=0.016$ ), and most of the variation were observed among groups (68.84\%).

Historical demography: The Bayesian skyline reconstruction showed a population expansion in the Isla del Coco population of Gobiesox adustus ca. 200,000-150,000 years ago (HDP 95 \%) (Fig. 3).

\section{DISCUSSION}

Data on the genetic structure of widely distributed fish populations in the Eastern Tropical Pacific (ETP) is scarce and the role played by the oceanic islands of the ETP in this structuring of populations remains poorly studied. 


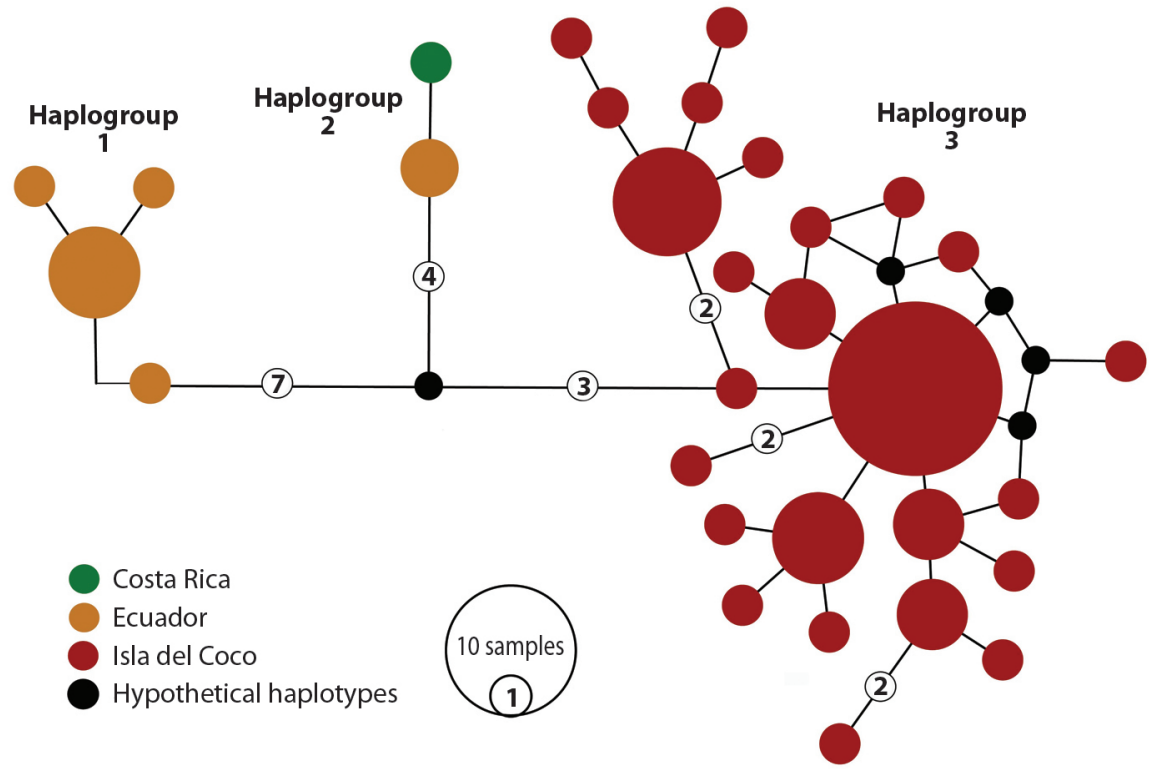

Fig. 2. Haplotype network of Gobiesox adustus based on a partial fragment of the cox 1 gene. The size of the circles is proportional to the frequency of each haplotype and colors correspond to sampled areas as show in figure 1. Numbers inside circles correspond to mutation steps, when more than one. Black circles correspond to hypothetical haplotypes.

TABLE 2

Genetic diversity of the three haplogroups found in the network of Gobiesox adustus based on cox 1 mitochondrial gene

\begin{tabular}{lccccc} 
& $\mathrm{N}$ & $\mathrm{S}$ & $\mathrm{nH}$ & $\mathrm{h}$ & $\pi$ \\
Haplogroup 1 (Ecuador) & 8 & 3 & 4 & $0.643 \pm 0.033$ & $0.00125 \pm 0.00044$ \\
Haplogroup 2 (Costa Rica-Ecuador) & 3 & 1 & 2 & $0.667 \pm 0.098$ & $0.00322 \pm 0.00152$ \\
Haplogroup 3 (Isla del Coco) & 58 & 21 & 25 & $0.883 \pm 0.033$ & $0.00443 \pm 0.0000002$ \\
All samples & 69 & 34 & 31 & $0.913 \pm 0.0006$ & $0.00883 \pm 0.00106$ \\
\hline
\end{tabular}

$\mathrm{N}$, number of samples; S, polymorphic sites; $\mathrm{nH}$, number of haplotypes; $h$, haplotype diversity; $\pi$, nucleotide diversity.

TABLE 3

Differentiation parameters for Gobiesox adustus coxl haplogruoups. Above diagonal: uncorrected $p$ genetic distances. Below diagonal: genetic differentiation using pairwise $\Phi$ ST among recovered haplogroups. * Significance value $(p<0.05)$.

\begin{tabular}{|c|c|c|c|}
\hline & $\begin{array}{l}\text { Haplogroup } 1 \\
\text { (Ecuador) }\end{array}$ & $\begin{array}{c}\text { Haplogroup } 2 \\
\text { (Costa Rica-Ecuador) }\end{array}$ & $\begin{array}{l}\text { Haplogroup } 3 \\
\text { (Isla del Coco) }\end{array}$ \\
\hline Haplogroup 1 (Ecuador) & & $2.1 \%$ & $2.1 \%$ \\
\hline Haplogroup 2 (Costa Rica-Ecuador) & $0.941^{*}$ & & $1.6 \%$ \\
\hline Haplogroup 3 (Isla del Coco) & $0.811^{*}$ & $0.732 *$ & \\
\hline
\end{tabular}




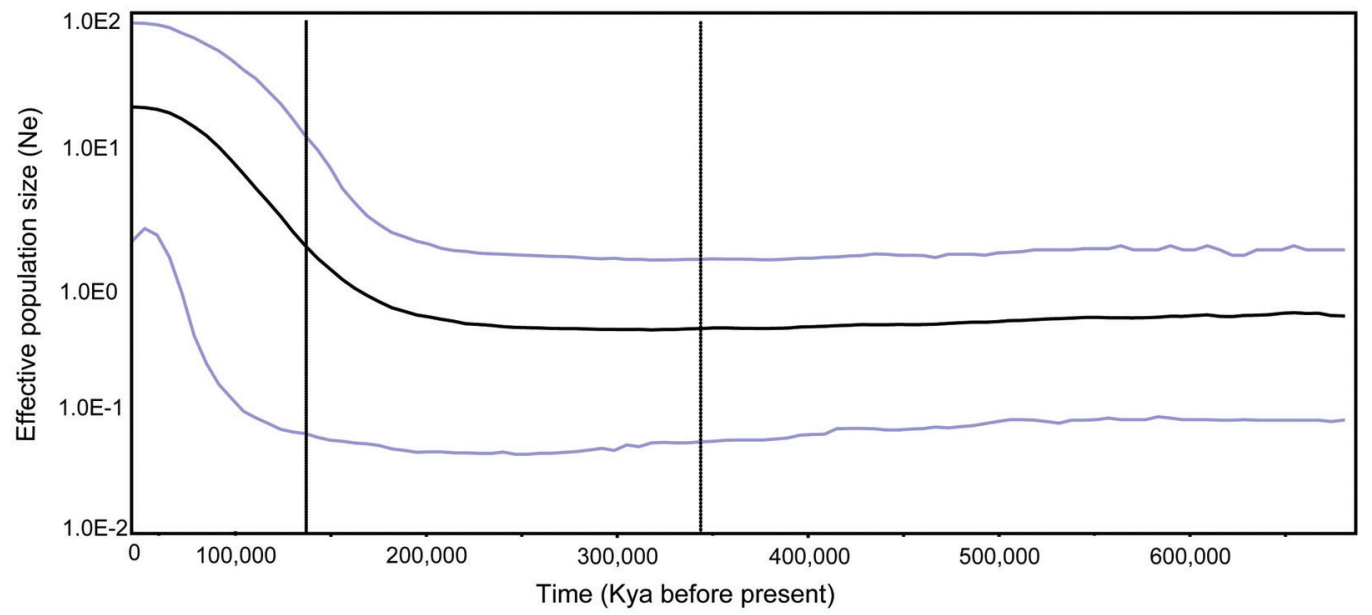

Fig. 3. Isla del Coco Gobiesox adustus population growth through time, historical reconstruction was performed using Bayesian skyline plot. Black line is the median effective population size. Blue lines are confidence intervals.

In the studies that do exist (i.e., Stethojulis bandaenensis, Porites lobata), genetic differentiation of populations from islands such as Clipperton and Isla del Coco has been recorded (Lessios \& Robertson, 2006; Baums, Boulay, Polato, \& Hellberg, 2012; Lessios \& Baums, 2016). A phylogeographic approach to investigate the evolution of Gobiesox adustus in the ETP with a focus in Isla del Coco is presented herein. This is the first study of the genetic diversity of clingfish from Isla del Coco and to evaluates the time of population expansion in fish species that habitat Isla del Coco.

Independence of evolutionary lineage from Isla del Coco. The genetic structure, high and significant $\Phi S T$ values, AMOVA results, the presence of unique haplotypes and high uncorrected genetic distances of 1.6 to $2.1 \%$ between the Gobiesox adustus from Isla del Coco haplogroup (haplogroup 3) vs haplogroups 1 and 2, show that the Isla el Coco haplogroup is a welldifferentiated lineage (Table 3 ). The consensus genetic divergences value of cox 1 widely used to suggest the existence of independent evolutionary units (Blaxter et al., 2005; DomínguezDomínguez \& Vázquez-Domínguez, 2009) and detect cryptic species have been placed at $2.0 \%$ (Steinke, Zemlak, \& Herbert, 2009; Asgharian,
Sahafi, Ardalan, Shekarriz, \& Elahi, 2011; April, Hanner, Dion-Côté, \& Bernatchez, 2012; Winterbottom, Hanner, Burridge, \& Zur, 2014). In this case, the population of G. adustus from Isla del Coco, suggests an independent evolutionary unit and could represent a discreet speciation process. Similar genetic differentiation values were found for several populations in marine fish species as in Chysiptera (Steinke et al., 2009), Trimma (Winterbottom et al., 2014), Bathybogius (Tornabene, Baldwin, Weigt, \& Pezold, 2010), Macrourus (Smith et al., 2011), Inegocia (Puckridge, Andreakis, Appleyard, \& Ward, 2013) were divergent haplogroups were recognized as provisional candidate species based in the $>2 \%$ differences in the coxl gene; in some cases the genetic results were consistent with minor taxonomic distinctions based on morphology (Quattro et al., 2006; Puckridge et al., 2013; Winterbottom et al., 2014) and even some well recognized marine fish species have genetic divergences lower than 2\% (Ward et al., 2005, Lowenstein, Amato, \& Kolokotronis, 2009) or different lineages Argyrops spinifer (Asgharian et al., 2011). As such, we propose that Gobiesox adustus population from Isla del Coco must to be considered as independent evolutionary linage pending of more deep study including more samples 
along the distribution range and integrative taxonomic analyses.

Significant differences in mtDNA frequencies between populations of Gobiesox adustus could be produced by a combination of the life history traits and oceanographic conditions. Data on the life history of G. adustus, such as its reproductive period, or the pelagic larval duration (PLD) are unknown. In general, a short PLD has been estimated for clingfish (i.e., 13-14 days) (Beldade, Pedro, \& Gonçalves, 2007). Several studies have shown that PLD has a positive correlation with the range of distribution of some species (Riginos \& Victor, 2001; Robertson, 2001; Macpherson \& Raventos, 2006; Kelly \& Palumbi, 2010). However, for other species this relationship is not as clear (Victor \& Wellington, 2000). Some studies in the Gulf of California show all stages of developing clingfish larvae can be found near reefs, indicating strong larval retention in and around the reef habitat (Brogan, 1994; Beldade et al., 2007). These characteristics of clingfish can maintain self-recruitment and, as a result, promote genetic differentiation in oceanic island populations, as in the case of G. adustus from Isla del Coco presented herein.

Another factor that could affect clingfish populations are the oceanographic processes that may reduce gene flow, generating significant genetic differentiation in populations. Oceanographic processes (i.e., currents and cyclonic/anticyclonic gyres) have a great influence on the marine ecosystems of the ETP and can promote retention or concentration of pelagic larvae, affecting the dispersal and the recruitment of fish species (Aceves-Medina et al., 2004; Contreras-Catala, Sánchez-Velasco, Lavín, \& Godínez, 2012; Pantoja, Marinone, Parés-Sierra, \& Gómez-Valdivia, 2012). Isla del Coco is influenced by the North Equatorial Countercurrent (NECC), the dynamic processes of the Costa Rica Dome (CRD), the Peruvian upwelling, and an anticyclonic circulation to the south of the island (Lizano, 2008). Accordingly, the short larval duration, the isolation of the oceanic Isla del Coco and the abovementioned oceanographic conditions, may restrict gene flow between of populations from Isla del Coco and the continent (Fig. 2), by limiting $G$. adustus dispersal.

All these processes play a fundamental role in the genetic structure of species associated with rocky reefs in the ETP (Hastings, 2000; Sandoval-Huerta et al., 2018), and particularly in oceanic island species, as is the case of Epinephelus labriformis and E. clippertonensis were private haplotypes of the Clipperton Athol and Alijos rocks populations indicate gene flow restriction between Clipperton Atoll, Alijos Rocks and the mainland due to oceanographic conditions, concluding that the formation of this sister species is a case of incipient speciation in the marine environment (Craig, Hastings, Pondella, Robertson, \& Rosales-Casián, 2006). Similar scenarios are present in the marine populations of other islands (Cunha et al., 2011) and Cape Mendocino, US, were the south-flowing California current, strong upwelling jets and seasonal offshore currents may form a barrier that has a structuring effect on some marine populations (Kelly \& Palumbi, 2010).

Historical demography: The changes in climate that occurred in the Pleistocene directly influenced changes of sea levels (Shen, Jamandre, Hsu, Tzeng, \& Durand, 2011), and this changes had a great influence on the contemporary distribution, abundance and evolutionary histories of a large number of species, including fish (Grant \& Bowen, 1998; Thacker, 2004; Barber \& Bellwood, 2005; Floeter et al., 2008; Kašparová, Van de Putte, Marshall, \& Janko, 2015), generating a genetic footprint on affected species (Hewitt, 2000; Avise, 2001). In Gobiesox adustus of Isla del Coco, the star-like haplotype network, high haplotype diversity, and low nucleotide diversity support a population expansion scenario, with, expansion dates calculated by the Bayesian Skyline Plot analysis at 200,000-150,000 years ago (95\%HPD) (Fig. 3). This period corresponds to the Middle Pleistocene, a time marked by the beginning of an interglacial period (240-190 kya), followed by the Illinoian glacial period (190-125 kya), 
with sea levels as low as $-130 \mathrm{~m}$ below present during Illinoian (Rohling et al., 1998). During periods of falling sea level, coastline geomorphology is modified and islands increase in area (Graham, Dayton, \& Erlandson, 2003) providing extra habitats for benthic species, which frequently promote the increase in effective population size in marine species (Marko et al., 2010; Cunha et al., 2011). For Isla del Coco have been estimated that the actual shallow habitat $\left(<50 \mathrm{~m}\right.$ deep) is $14 \mathrm{~km}^{2}$, being much higher during periods of falling sea level (110 $\mathrm{Km}^{2}$ ) (Robertson, 2001). Accordingly, since the estimation of the demographic expansion in G. adustus from Isla del Coco coincide with the Illinoian glacial period with sea levels as low as $-130 \mathrm{~m}$ below present, we expect a scenario were the habitat availability in the island increase considerably, favoring the population expansion of $G$. adustus populations.

Conservation implications: The knowledge about the natural populations, at different levels, from the genetic diversity of the populations to the specific richness of an ecosystem, should be an important part of the decision making process for the protection and conservation of species and areas, moreover in populations living in natural protected areas. Conservation efforts should not be limited to species of commercial interest; it is also necessary to include highly diverse ecosystems, such as reefs or intertidal zones (Perkins, Ng, Dudgeon, Bonebrake, \& Leung, 2015). The information presented herein, of an evolutionary distinct population of $G$. adustus from Isla del Coco should be taken in consideration in the conservation desertions for Isla del Coco National Park, specifically for the importance of the conservation of intertidal zone to maintain the entire diversity of the park (Rocha, Craig, \& Bowen, 2007; DomínguezDomínguez \& Vázquez-Domínguez, 2009). Robertson (2001) proposed that small oceanic islands (like Isla del Coco) be considered as small reserves as they represent hotspots of diversity and endemism, in this case, the use of genetic information, such as that presented herein, allows the identification and help in the establishment of marine reserves and protection priorities of endemism and diversity hotspots (Jones, Srinivasan, \& Almany, 2007; Almany et al., 2009; Planes, Jones, \& Thorrold, 2009; Drew \& Barber, 2012).

The strong population differentiation for Gobiesox adustus in Isla del Coco is influenced by life history traits and the oceanographic conditions. Further study and conservation of the G. adustus population of Isla del Coco will be important as part of conserving the biodiversity of the oceanic islands of the ETP. There is still a lot of work to be done, with respect to the populations of G. adustus, in particular it is recommended to perform integrative taxonomic study in order to elucidate the distinctiveness of this population.

Ethical statement: authors declare that they all agree with this publication and made significant contributions; that there is no conflict of interest of any kind; and that we followed all pertinent ethical and legal procedures and requirements. All financial sources are fully and clearly stated in the acknowledgements section. A signed document has been filed in the journal archives.

\section{ACKNOWLEDGMENTS}

ETH would like to thank the Programa de Posgrado en Ciencias del Mar y Limnología, UNAM and CONACYT for fellowship support. This work was supported by funding provided by the CONACYT-CB-2014-240875 and CIC-UMSNH 2016-2019. We thank Esteban Herrera and Issac Chinchilla (ACMC-SINAC); Jonathan Valdiviezo Rivera and Diego Inclan Luna (INABIO-Ecuador); Carmen Pedraza, Sesángari Galván, Omar Valencia, Cecilia Mesen, Beatriz Naranjo, Francisco Martinez, Yareli López, and the members of the CPUM for their collaboration in sampled process. We 
also thanks to Tom Jameson from Chester Zoo. We thank the associate editor, Jairo A. Arroyave Guitierrez and one anonymous reviewers for constructive comments on a previous version of the manuscript. Organism collection was supported and allowed by the following institutions and permits by Costa Rica (0072013-SINAC; R-056-2105-OT-CONAGE$\mathrm{BIO})$, and Ministerio del Ambiente Ecuador (N²1-2017-EXP-CM-2016-DNB/MA).

\section{RESUMEN}

Linaje evolutivo independiente del clingfish Gobiesox adustus (Gobiesocidae) de Isla del Coco, Costa Rica. Introducción: Isla del Coco es un área protegida importante para la fauna marina en el Pacifico Oriental Tropical. En esta área, las especies que habitan la zona intermareal han sido objeto de pocos estudios. Una de las especies que habitan en estas áreas es el clingfish Gobiesox adustus (Gobiesocidae). Objetivo: Analizar por primera vez el gen mitocondrial citocromo oxidasa sub unidad 1 ( $\operatorname{cox} 1)$ de poblaciones de Isla del Coco y compararlo con las de la zona continental de Costa Rica y Ecuador. Métodos: Se construyó una red de haplotipos. La diversidad, la distancia y la estructura genética fueron calculadas por diversos programas. La demografía histórica de las muestras de Isla del Coco fue evaluada con el método Bayesian skyline plot implementado en BEAST2. Resultados: Las muestras se agruparon en tres haplogrupos: en un haplogrupo se incluyó a los individuos de Isla del Coco, otro haplogrupo integró las muestras de Ecuador y un tercer grupo incluyó las muestras restantes de Costa Rica y Ecuador. Las distancias genéticas entre los tres haplogrupos oscilan entre $1.6 \%$ y $2.1 \%$ ( $p$-distancia, no corregida), las distancias ФST y los resultados de AMOVA entre los tres haplogrupos muestran valores altos y significativos. Conclusiones: El haplogrupo de Isla del Coco mostró un crecimiento poblacional datado en el Pleistoceno, coincidiendo con la demografía poblacional encontrada en otros organismos marinos. La historia de aislamiento de la población de $G$. adustus de Isla del Coco demostró la independencia evolutiva de esta población.

Palabras clave: Clingfish, criptobéntico, isla oceánica, pez marino, intermareal, Pacífico Oriental Tropical.

\section{REFERENCES}

Aceves-Medina, G., Jiménez-Rosenberg, S. P. A., Hinojosa-Medina, A., Funes-Rodríguez, R., SaldiernaMartínez, R. J., \& Smith, P. E. (2004). Fish larvae assemblages in the Gulf of California. Journal of Fish Biology, 65, 832-847.
Ackerman, J. L., \& Bellwood, D. R. (2000). Reef fish assemblages: a re-evaluation using enclosed rotenone stations. Marine Ecology Progress Series, 206, 227-237.

Ackerman, J. L., \& Bellwood, D. R. (2002). Comparative efficiency of clove oil and rotenone for sampling reef fish assemblages. Journal of Fish Biology, 60, 893-901.

Almany, G. R., Connolly, S. R., Health, D. D., Hogan, J. D., Jones, G. P., McCook, L. J., Mills, M., Pressey, R. L., \& Williamson, D. H. (2009). Connectivity, biodiversity conservation and the design of marine reserve networks for coral reefs. Coral Reefs, 28, 339-351.

Al-Rshaidat, M. M. D., Snider, A., Rosebraugh, S., Devine, A. M. Devine, T. D., Plaisance, L., Knowlton, N., \& Leray, M. (2016). Deep COI sequencing of standardized benthic samples unveils overlooked diversity of Jordanian coral reefs in the northern Red Sea. Genome, 59, 724-737.

Andújar, C., Arribas, P., Yu, D. W., Vogler, A. P., \& Emerson, B. C. (2018). Why the COI barcode should be the community DNA metabarcode for the metazoan. Molecular Ecology, 27, 3968-3975.

April, J., Hanner, R. H., Dion-Côté, A. M. \& Bernatchez, L. (2012). Glacial cycles as an allopatric speciation pump in north-eastern American freshwater fishes. Molecular Ecology, 22(2), 409-422.

Asgharian, H., Sahafi, H. H., Ardalan, A. A., Shekarriz, S., \& Elahi, E. (2011). Cytochrome c oxidase subunit 1 barcode data of fish of the Nayband National Park in the Persian Gulf and analysis using meta-data flag several cryptic species. Molecular Ecology Resources, 11, 461-472.

Avise, J. C. (2001). Evolving genomic Metaphors: a new look at the Language of DNA. Science, 294, 86-87.

Bandelt, H. J., Forster, P., \& Röhl, A. (2000) Median-Joining networks for inferring intraspecific phylogenies. Molecular Biology and Evolution, 16, 37-48.

Barber, P. H., \& Bellwood, D. R. (2005). Biodiversity hotspots: evolutionary origins of biodiversity in wrasses (Halichoeres: Labridae) in the Indo-Pacific and new world tropics. Molecular Phylogenetics and Evolution, 35, 235-253.

Baums, I. B., Boulay, J. N., Polato, N. R., \& Hellberg, M. E. (2012). No gene flow across the Eastern Pacific Barrier in the reef-building coral Porites lobata. Molecular Ecology, 21, 5418-5433.

Beldade, R., Pedro, T., \& Gonçalves, E. J. (2007). Pelagic larval duration of 10 temperature cryptobenthic fishes. Journal of fish Biology, 71, 376-382.

Bellwood, D. R., Baird, A. H., Depczynski, M., GonzálezCabello, A., Hoey, A. S., Lefévre, C. D. \& Tanner, J. 
K. (2012). Coral recovery may not herald the return of fishes on damaged coral reefs. Oecologia, 170, 567-573.

Bouckaert, R., Heled, J., Kühnert, D., Vaughan, T., Wu, C-H., Xie, D., Suchard, MA., Rambaut, A., \& Drummond, A. J. (2014). BEAST 2: A Software Platform for Bayesian Evolutionary Analysis. PLoS Computational Biology, 10(4), e1003537. doi:10.1371/journal. pcbi. 1003537

Blaxter, M., Mann, J., Chapman, T., Thomas, F., Whitton, C., Floyd, R., \& Abebe, E. (2005). Defining operational taxonomic units using DNA barcode data. Philosophical transactions of the Royal Society B: Biological Sciences, 360, 1935-1943.

Brandl, S. J., Goatley, C. H. R., Bellwood, D. R., \& Tornabene, L. (2018). The hidden half: ecology and evolution of cryptobenthic fishes on coral reefs. Biological Rewiews, 93, 1846-1873. doi:10.1111/brv.12423

Briggs, J.C., \& Bowen, B.W. (2012). A realignment of marine biogeographic provinces with particular reference to fish distributions. Journal of Biogeography, $39,12-30$.

Brogan, M. W. (1994). Distribution and retention of larval fishes near reefs in the Gulf of California. Marine Ecology Progress Series, 115, 1-13.

Contreras-Catala, F., Sánchez-Velasco, L., Lavín, M. F., \& Godínez, V. M. (2012). Three-dimensional distribution of larval fish assemblages in an anticyclonic Eddy in a semi-enclosed sea (Gulf of California). Journal of Plankton Research, 34(6), 548-562.

Conway, K.W., Kim, D., Rüber, L., Espinosa-Pérez, H. S., \& Hastings, P. A. (2017). Molecular systematics of the New World clingfish genus Gobiesox (Teleostei: Gobiesocidae) and the origin of a freshwater clade. Molecular Phylogenetics and Evolution, 112, 138-147.

Cortés, J. (2008). Historia de la investigación marina de la Isla el Coco, Costa Rica. Revista de Biología Tropical, 56(Supplement 2), 1-18.

Cortés, J. (2012). Marine biodiversity of an Eastern Tropical Pacific oceanic island, Isla del Coco, Costa Rica. Revista de Biología Tropical, 60(Supplement 3), 131-185.

Cortés, J., Sánchez-Jiménez, A., Rodríguez-Arrieta, J. A., Quirós-Barrantes, G., González, P. C., \& Blum, S. (2012). Elasmobranchs observed in deepwaters (45-330m) at Isla del Coco National Park, Costa Rica (Eastern Tropical Pacific). Revista de Biología Tropical, 60(Suppement 3), 257-273.

Craig, M.T., Hastings, P.A., Pondella, D.J., Robertson, D.R., \& Rosales-Casián, J.A. (2006). Phylogeography of the flag cabrilla Epinephelus labriformis (Serranidae): implications for the biogeography of the Tropical Eastern Pacific and the early stages of speciation in a marine shore fish. Journal of Biogeography, 33, 969-979.

Cunha, R. L., Lopes, E. P., Reis, D. M. \& Castilho, R. (2011). Genetic structure of Brachidontes puniceus populatons in Cape Verde Archipielago shows signature of expansion during the last Glacial Maximum. Journal of Molluscan Studies, 77, 175-181.

Mar, R. L., Lopes, E. P., Reis, D. M., \& Castilho, R. (2010). Genetic structure of Brachidontes puniceus populations in Cape Verde archipelago shows signature of expansion during the last glacial maximum. Journal of Molluscan Studies, 77, 175-181.

Depczynski, M., \& Bellwood, D. R. (2003). The role of cryptobenthic reef fishes in coral reef trophodynamics. Marine Ecology Progress Serie, 256, 183-191.

Domínguez-Domínguez, O., \& Vázquez-Domínguez, E. (2009). Filogeografía: aplicaciones en taxonomía y conservación. Animal Biodiversity and Conservation, 32(1), 59-70.

Drew, J. A., \& Barber, P. H. (2012). Comparative Phylogeography in Fijian Coral Reef Fishes: A Multi-Taxa Approach towards Marine Reserve Design. PLoS ONE, 7(10), e47710.

Drummond, A. J., Rambaut, A., Shapiro, B., \& Phybus, O. G. (2005). Bayesian Coalescent Inference of past population dynamics for molecular sequences. Molecular Biology and Evolution, 22, 1185-1192.

Dupanloup, I., Schneider, S., \& Excoffier, L. (2002). A simulated annealing approach to define the genetic structure of populations. Molecular Ecology, 11(12), 2571-81.

Emerson, B. C., \& Kolm, N. (2005). Species diversity can drive speciation. Nature, 434, 1015-1017.

Excoffier, L., \& Lischer, H. E. L. (2010). Arlequin ver. 3.5: A new series of programs to perform population genetics analyses under Linux and Windows. Molecular Ecology Resources, 10, 564-567.

Excoffier, L., Smouse, P. E. \& Quattro, J. M. (1992). Analysis of molecular variance inferred from metric distances among DNA haplotypes: application to human mitochondrial DNA restriction data. Genetics, $131,479-491$.

Floeter, S. R., Rocha, L. A., Robertson, D. R., Joyeux, J. C., Smith-Vaniz, W. F., Wirtz, P., Edwards, A. J., Barreiros, J. P., \& Ferreira, C. E. L. (2008). Atlantic reef fish biogeography and evolution. Journal of Biogeography, 35, 22-47.

Folmer, O., Black, M., Hoeh, W., Lutz, R. \& Vrijenhoek, R. (1994). DNA primers for amplification of mitochondrial cytochrome $c$ oxidase subunit from diverse 
metazoan invertebrates. Molecular Marine Biology and Biotechnology, 3(5), 294-299.

Fourriére, M., Alvarado, J.J., Ayala-Bocos, A., \& Cortés, J. (2017). Updated checklist and analysis of completeness of the marine fish fauna of Isla del Coco, Pacific of Costa Rica. Marine Biodiversity, 47, 813-821.

Garrison, G. (2000). Peces de la Isla del Coco. San José, Costa Rica, Editorial INBio.

Gonzáles-Andrés, C., Lopes, P. F. M., Cortés, J., SánchezLizaso, J. L., \& Pennino, M. G. (2016). Abundance and Distribution Patterns of Thunnus albacares in Isla del Coco National Park through Predictive Habitat Suitability Models. PLoS ONE, 11(12), e0168212.

Graham, M. H., Dayton, P. K. \& Erlandson, J. M. (2003). Ice ages and ecological transitions on temperate coasts. TRENDS in Ecology and Evolution, 18(1), $33-40$.

Grant, W. S., \& Bowen, B. W. (1998). Shallow population histories in deep evolutionary lineages of marine fishes: insights from sardines and anchovies and lessons for conservation. Journal of Heredity, 89(1), 415-426.

Hachich, N. F., Bonsall, M. B., Arraut, E. M., Bameche, D. R., Lewinsohn, T. M., \& Floeter, S. R. (2015). Journal of Biogeography, 42, 1871-1882.

Hastings, P. A. (2000). Biogeography of the Tropical Eastern Pacific: distribution and phylogeny of chaenopsid fishes. Zoological Journal of the Linnean Society, 128, 319-335.

Hebert, P. D. N., Cywinska, A., Ball, S. L., \& deWaard, J. R. (2003a). Biological identifications through DNA barcodes. Proceedings of the Royal Society of London Series B-Biological Sciences, 70, 313-321.

Hebert, P. D. N., Ratnasingham, S., \& deWaard, J. R. (2003b). Barcoding animal life: cytochrome c oxidase subunit 1 divergences among closely related species. Proceedings of the Royal Society of London Series B Biological Sciences, 270, S96-S99.

Hewitt, G. (2000). The genetic legacy of the Quaternary ice. Nature, 405, 907-913.

Hollingsworth, P. M., Graham, S. W., \& Little, D. P. (2011). Choosing and Using a Plant DNA Barcode. PLoS ONE, 6(5), e19254.

Jones, G. P., Srinivasan, M., \& Almany, G. R. (2007). Population Connectivity and Conservation of Marine Biodiversity. Oceanography, 20(3), 100-111.

Kašparová, E., Van de Putte, A. P., Marshall, C., \& Janko, K. (2015). Lifestyle and Ice: The relationship between ecological specialization and response to Pleistocene climate change. PloS ONE, 10(11), e0138766.
Keith, P., Lord, C., Lorion, J., Watanabe, S., Tsukamoto, K., Couloux, A., \& Dettai, A. Phylogeny and biogeography of Sicydiinae (Teleostei: Gobiidae) inferred from mitochondrial and nuclear genes. Marine Bio$\log y, 158,311-326$.

Kelly, R. P., \& Palumbi, S. R. (2010). Genetic structure among 50 Species of the Northeastern Pacific rocky intertidal community. PLoS ONE, 5(1), e8594.

Kumar, S., Stecher, G., \& Tamura, K. (2016). MEGA7: Molecular Evolutionary Genetics Analysis version 7.0 for bigger datatets. Molecular Biology and Evolution, 33, 1870-1874.

Lessios, H. A., \& Baums, I. B. (2016). Gene flow in coral reef organisms of the Tropical Eastern Pacfic, In: Glynn, P. W., Manzello, D. P. \& Enochs, I. C. (Eds.). Coral Reefs of the Eastern Tropical Pacific, Coral Reefs of the World, 8, 477-499.

Lessios, H. A., \& Robertson, D. R. (2006). Crossing the impassable: genetic connections in 20 reef fishes across the eastern Pacific barrier. Proceedings of the Royal Society B, 273, 2201-2208.

Librado, P., \& Rozas, J. (2009). DnaSP v5: A software for comprehensive analysis of DNA polymorphism data. Bioinformatics, 25, 1451-1452.

Lizano, O. G. R. (2008). Dinámica de aguas alrededor de la Isla de Coco, Costa Rica. Revista de Biología Tropical, 56(Supplement 2), 31-48.

Losos, J. B., \& Ricklefs, R. E. (2009). Adaptation and diversification on islands. Nature, 457, 830-850.

Lowenstein, J. H., Amato, G., \& Kolokotronis, S. O. (2009). The Real maccoyii: identifying tuna sushi with DNA Barcodes - Contrasting characteristic attributes and genetic distances. PLoS ONE, 4(11), e 7866. doi:10.1371/journal.pone.0007866

Macpherson, E., \& Raventos, N. (2006). Relationship between pelagic larval duration and geographic distribution of Mediterranean littoral fishes. Marine Ecology Progress Series, 327, 257-265.

Marko, P. B., Hoffman, J. M., Emme, S. A., McGovern, T. M., Keever, C. C., \& Cox, N. L. (2010). The 'Expansion-Contraction' model of Pleistocene biogeography: rocky shores suffer a sea change?. Molecular Ecology, 19, 146-169.

Miller, M. A., Pfeiffer, W., \& Schwartz, T. (2010). Creating the CIPRES Science Gateway for inference of large phylogenetic trees. Proceedings of the Gateway Computing Environments Workshop (GCE), New Orleans, LA pp 1-8.

Pantoja, D. A., Marinone, S. G., Parés-Sierra, A., \& Gómez-Valdivia, F. (2012). Modelación numérica de la hidrografía y circulación estacional y de 
mesoescala en el Pacífico Central Mexicano. Ciencias Marinas, 38(2), 363-379.

Perkins, M. J., Ng, T. P. T., Dudgeon, D., Bonebrake, T. C., \& Leung, K. M. Y. (2015). Conserving intertidal habitats: What is the potential of ecological engineering to mitigate impacts of coastal structures? Esturine, Coastal and Shelf Science, 167, 504-515.

Planes, S., Jones, G. P., \& Thorrold, S. R. (2009). Larval dispersal connects fish populations in a network of marine protected areas. Proceedings of the National Academy of Sciences of the United States of America, 106(14), 5693-5697.

Posada D. (2008). jModelTest: Phylogenetic Model Averaging. Molecular Biology and Evolution, 25, 1253-1256.

Puckridge, M., Andreakis, N., Appleyard, S. A. \& Ward, R. D. (2013). Cryptic diversity in flathead fishes (Scorpaeniformes: Platycephalidae) across the Indo-West Pacific uncovered by DNA barcoding. Molecular Ecology Resources, 13, 32-42.

Quattro, J. M., Stoner, D. S., Driggers, W. B., Anderson, C. A., Priede, K. A., Hoppmann, E. C., Campbell, N. H., Duncan, K. M., \& Grady, J. M. (2006). Genetic evidence of cryptic speciation with hammerhead sharks (Genus Sphyrna). Marine Biology, 148(5), 1143-1155

Rambaut, A., \& Drummond, A. J. (2007) Tracer v1.4, Available from http:// beast.bio.ed.ac.uk/Tracer

Riginos, C., \& Victor, B. C. (2001). Larval spatial distributions and other early life-history characteristics predict genetic differentiation in eastern Pacific blenniod fishes. Proceedings of the Royal Society of London. Series B: Biological Sciences, 268, 1-6.

Robertson, D. R. (2001). Population maintenance among tropical reef fishes: Inferences from small-island endemics. Proceedings of the National Academy of Sciences of the United States of America, 98(10), $5667-5670$

Robertson, D. R., \& Allen, G. R. (2015). Shorefishes of the Tropical Eastern Pacific: online information system. Version 2.0. Smithsonian Tropical Research Institute, Balboa, Panamá. https://biogeodb.stri.si.edu/sftep/en/ pages

Robertson, D. R., \& Cramer, K. L. (2009). Shore fishes and biogeographic subdivisions of the Tropical Eastern Pacific. Marine Ecology Progress Series, 380, 1-17.

Robertson, D. R. \& Smith-Vaniz, W. F. (2008). Rotenone: an essential but demonized tool for assessing marine fish diversity. Bioscience, 58, 165-170.

Rocha, L. A., Craig, M. T., \& Bowen, B. W. (2007). Phylogeography and the conservation of coral reef fishes. Coral Reefs, 26: 501-512.
Rohling, E. J., Fenton, M., Jorissen, F. J., Bertrand, P., Ganssen, G., \& Caulet, J. P. (1998). Magnitudes of sea-level lowstands of the past 500,000 years. Nature, $394,162-165$.

Sáenz, A. G. (2009). Genes y especies. Ecosistemas, 18(1), 3-9.

Sambrook, J., Fritsch, E. F., \& Maniatis, T. (1989). Molecular cloning: A laboratory manual (2nd ed.). New York, NY. Cold Spring Harbor Laboratory.

Sandoval-Huerta, E. R., Beltrán-López, R. G., PedrazaMarrón, C. R., Paz-Velásquez, M. A., Angulo, A., Robertson, D. R., Espinoza, E., \& DomínguezDomínguez, O. (2018). The evolutionary history of the goby Elacatinus puncticulatus in the tropical eastern pacific: Effects of habitat discontinuities and local environmental variability. Molecular Phylogenetics and Evolution, 130, 269-285.

Shen, K. N., Jamandre, B. W., Hsu, C. C., Tzeng, W. N., \& Durand, J. D. (2011). Plio-Pleistocene sea level and temperature fluctuations in the northwestern Pacific promoted speciation in the globally-distributed flathead mullet Mugil cephalus. Bio Med Central Evolutionary Biology, 11, 83.

Smith, P. J., Steinke, D., McMillan, P. J., Stewart, A. L., McVeagh, S. M., Diaz de Astarloa, J. M., Welsford, D., \& Ward, R. D. (2011). DNA barcoding highlights a cryptic species of grenadier Macrourus in the Southern Ocean. Journal of Fish Biology, 78, 355-365.

Steinke, D., Zemlak, T. S., \& Herbert, D. N. (2009). Barcoding Nemo: DNA-Based identifications for the ornamental fish trade. PloS ONE, 4(7), e6300.

Tornabene, L., Baldwin, C., Weigt, L. A. \& Pezold, F. (2010). Exploring the diversity of western Atlantic Bathygobius (Teleostei: Gobiidae) with cytochrome c oxidase-I, with descriptions of two new species. Aqua International Journal of Ichthyology, 16(4), 141-170.

Torres-Hernández, E., Palacios-Morales, G., RomeroGallardo, S., Salazar-Araujo, P., García-Meraz, A., Madrigal-Guridi, X., Del Moral-Flores, LF. \& Domínguez-Domínguez, O. (2016) Annotated checklist of the coastal ichthyofauna from Michoacán State, Mexico. ZooKeys, 606, 99-126.

Thacker, C. E. (2004). Population structure in two species of the reef goby Gnatholepis (Teleostei: Perciformes) among four South Pacific island groups. Coral Reefs, 23, 357-366.

Thomson, D. A., Findley, L., \& Kerstitch, A. N. (2000). Reef Fishes of the Sea of Cortéz: The Rocky-Shore Fishes of the Gulf of California. Tucson, Arizona: The University of Arizona Press. 
Valdéz-Moreno, M., Vásquez-Yeomans, L., Elías-Guitiérrez, M., Ivanova, N.V., \& Hebert, P.D.N. (2010). Using DNA barcodes to connect adults and early life stages of marine fishes from the Yucatan Peninsula, Mexico: potential in fisheries management. Marine and Freshwater, 61, 665-671.

Victor, B.C., \& Wellington, G. M. (2000). Endemism and the pelagic larval duration of reef fishes in the eastern Pacific Ocean. Marine Ecology Progress Series, 205, 241-248.

Ward, R. D., Zemlak, T. S., Innes, B. H., Last, P. R., \& Hebert, P. D. N. (2005). DNA barcoding Australia's fish species. Philosophical Transactions of the Royal Society of London Series B Biological Sciences, 360 , 1847-1857.
Weir, B. S. \& Cockerham, C. C. (1984). Estimating F-statistics for the analysis of population structure. Evolution, 38, 1358-1370.

Whittaker, R. J., Triantis K. A., \& Ladle, R. J. (2008). A general dynamic theory of oceanic island biogeography. Journal of Biogeography, 35, 977-994.

Willis, T. J. (2001). Visual census methods underestimate density and diversity of cryptic reef fishes. Journal of Fish Biology, 59, 1408-1411.

Winterbottom, R., Hanner, R. H., Burridge, M., \& Zur, M. (2014). A cornucopia of cryptic species- a DNA barcode analysis of the gobiid fish genus Trimma (Percomorpha, Gobiiformes). Zookyes, 381, 79-111. doi: 10.3897/zookeys.381.6445 